\section{Storage Quality and Composition of Sweetpotato Roots after Quarantine Treatment Using Low Doses of X-ray Irradiation}

\author{
Marisa M. Wall ${ }^{1}$ \\ U.S. Department of Agriculture, Agricultural Research Service, U.S. Pacific \\ Basin Agricultural Research Center, P.O. Box 4459, Hilo, HI 96720-0459
}

Additional index words. Ipomoea batatas, postharvest treatment, quality, carbohydrates, quarantine

\begin{abstract}
Sweetpotato [Ipomoea batatas (L.) Lam.] roots of three Hawaii-grown cultivars ('Mokuau', 'Okinawan', and 'Yoshida') were treated with 0, 200, or 400 Gy $x$-ray irradiation and stored for 12 weeks at $15^{\circ} \mathrm{C}$. The storage quality of nonirradiated and irradiated roots was compared for weight loss, sprouting, firmness, color, postharvest decay, and carbohydrate concentrations. Nonirradiated roots lost 3 to $4 \%$ weight during storage, whereas roots treated with $400 \mathrm{~Gy}$ lost $4.7 \%$ to $8.6 \%$ weight. Sprouting was negligible for all treatments. Storage tended to increase root firmness, while irradiation tended to decrease firmness. When all cultivars were averaged, sweetpotatoes treated with $400 \mathrm{~Gy}$ and stored for 12 weeks had the lowest starch concentrations and highest total sugar concentrations. Glucose and fructose concentrations were not affected by irradiation, but these sugars increased during storage. Sucrose concentrations of roots irradiated with $400 \mathrm{~Gy}$ were double those of nontreated roots after 12 weeks storage. The purple-fleshed cultivars, 'Mokuau' and 'Okinawan', retained good quality following irradiation and storage, but firmness decreased somewhat for roots treated with $400 \mathrm{~Gy}$. The 'Okinawan' sweetpotato is the primary export cultivar from Hawaii. For the white-fleshed cultivar, 'Yoshida', postharvest decay adversely impacted the internal color, firmness, and overall quality of roots treated with $400 \mathrm{~Gy}$ and stored for 12 weeks.
\end{abstract}

Hawaii-grown sweetpotatoes [Ipomoea batatas (L.) Lam.] cannot be shipped to mainland U.S. or international markets without being treated for quarantine security against insect pests. Hawaii has infestations of the sweetpotato weevil [Cylas formicarius elegantulus (Summers)], West Indian sweetpotato weevil [Euscepes postfasciatus (Fairmaire)] and the sweetpotato vine borer [Omphisa anastomosalis (Guenee)](U.S. Dept. Agriculture-APHIS-PPQ, 2002). Growers have been exporting sweetpotatoes to the U.S. mainland using methyl bromide fumigation, but methyl bromide adversely affects root quality and has become costly. Recently, the U.S. Dept. of Agriculture, Animal and Plant Health Inspection Service(USDA-APHIS) issued a final rule that allows for the movement of sweetpotatoes from Hawaii following irradiation with a minimum dose of 400 Gy (Federal Register, 2004).

The optimum irradiation dose for treating sweetpotatoes without affecting quality may lie

Received for publication 10 May 2004. Accepted for publication 11 Sept. 2004. Mention of a trademark, warranty, proprietary product, or vendor does not constitute a guarantee by the U.S. Dept. of Agriculture and does not imply its approval to the exclusion of other products or vendors that may be suitable. The author thanks Hector Valenzuela of the University of Hawaii at Manoa for supplying the sweetpotatoes for this study; John Clark and Eric Weinert of Hawaii Pride for providing irradiation services; Kate Nishijima and Brian Bushe for plant disease identification; and Suzanne Sanxter, Sandra Silva, and Ryan Bosma for excellent technical assistance.

1E-mail mwall@pbarc.ars.usda.gov.
'Okinawan' has white skin with purple flesh. 'Yoshida' roots have light red skin and white flesh. These cultivars are commonly grown in the Hawaiian islands and consumed by the local population. Roots were culled before curing for $10 \mathrm{~d}$ at $30{ }^{\circ} \mathrm{C}$ and $90 \%$ relative humidity (RH). Root weight averaged 217, 318, and 154 g for 'Mokuau', 'Okinawan', and 'Yoshida' cultivars, respectively.

Irradiation treatment. Cured sweetpotato roots $(6.75 \mathrm{~kg})$ were placed into fiberboard boxes for treatment at a commercial irradiation facility on the island of Hawaii (Hawaii Pride, Kea'au, Hawaii). Roots of the three cultivars were mixed together inside each box. The facility uses an electron linear accelerator (5 $\mathrm{MeV}$, model TB-5/15; SureBeam Corp., San Diego, Calif.) and converts the e-beam into $\mathrm{x}$-rays for treatment of produce. Dosimeters (Opti-chromic detectors, FWT-70-83M; Far West Technology, Goleta, Calif.) were placed at six locations inside and two locations outside each box. The dosimeters were read at $600 \mathrm{~nm}$ with a FWT-200 reader (Far West Technology) to determine the dose variation within each box. Roots were treated with target absorbed doses of 0,200 , or 400 Gy irradiation. Each irradiation dose was replicated four times. The average minimum and maximum absorbed doses inside the boxes were 205-226 and 398-442 Gy, with corresponding dose uniformity ratios of 1.10 and 1.11 for the 200 and 400 Gy target dose treatments, respectively. Following treatment, roots were stored at $15{ }^{\circ} \mathrm{C}$ and $85 \% \mathrm{RH}$ for 12 weeks. Control treatments ( 0 Gy) were not subjected to irradiation, but were cured and handled exactly the same as the treated roots, and were stored for 12 weeks.

Quality analyses. Quality and compositional analyses were performed on nonirradiated and irradiated roots before and after storage. Nondestructive quality assessments were made after $0,4,8$, and 12 weeks storage. Root weight, external color, disease incidence and severity, and sprouting incidence were recorded for three roots per sample at these times. The surface color of roots was quantified using a chromameter (Minolta Corp., Ramsey, N.J.) calibrated to a standard white reflective plate. Data were recorded as lightness $\left(\mathrm{L}^{*}\right)$, chroma $\left(\mathrm{C}^{*}\right)$, and hue angle $\left(\mathrm{h}^{\circ}\right)$. Color values were measured at three locations for each root. Disease severity for each root was rated as 0 (none), 1 (low), 2 (moderate), or 3 (severe) based on visual symptoms. Destructive quality analyses for root internal color, moisture content, firmness, starch content, and sugar concentrations were measured on three roots per sample stored for 0 or 12 weeks. Root firmness was measured using a force gauge (Ametek, Largo, Fla.) having a $6 \mathrm{~mm}$ wide chisel probe, and mounted on a motorized test stand. The peak force $(\mathrm{kg})$ was measured at a penetration depth of $7 \mathrm{~mm}$, and the data were converted to Newtons $(\mathrm{N})$. Roots were cut longitudinally and the internal flesh color was measured. A 10-g sample was removed from each root and dried in an oven at $70{ }^{\circ} \mathrm{C}$ for dry weight determinations. The remainder of the root halves were used for sugar and starch extractions. Grated root tissue $(10 \mathrm{~g})$ 
from two roots was combined in a glass test tube and homogenized in $80 \%$ ethanol for 1 min. at high speed. The slurry was immediately boiled for $15 \mathrm{~min}$., cooled, and filtered through Whatman \#4 paper. The filter cake was rinsed with additional ethanol, and dried for $48 \mathrm{~h}$ at $70{ }^{\circ} \mathrm{C}$ to obtain the alcohol insoluble solids (AIS) for starch analysis. The sugar extract was brought to a final volume of $100 \mathrm{~mL}$. A $5-\mathrm{mL}$ aliquot was filtered through a $0.22 \mu \mathrm{m}$ membrane filter into vials for high-pressure liquid chromatography (HPLC).

HPLC analysis. HPLC was used to separate and quantify glucose, fructose, and sucrose in roots using a modified method of Picha (1985). Carbohydrates were analyzed by injecting $20 \mu \mathrm{L}$ of sample into an Agilent 1100 series liquid chromatograph with premixed HPLCgrade water $(25 \%)$ and acetonitrile $(75 \%)$ as the mobile phase, and an aminopropylsilane column as the stationary phase (Agilent ZORBAX carbohydrate analysis column, $4.6 \mathrm{~mm}$ ID $\times 150 \mathrm{~mm}, 5 \mu \mathrm{m})$, followed by an Agilent refractive index detector (Agilent Technologies, Wilmington, Del.). A flow rate of $1.4 \mathrm{~mL} \cdot \mathrm{min}^{-1}$ was used, and the column and detector temperatures were set at $30^{\circ} \mathrm{C}$. The mobile phase was vacuum filtered through a $0.45-\mu \mathrm{m}$ membrane filter before use.

Sucrose, glucose, and fructose standards were prepared at five concentrations ranging from 250 to $2000 \mu \mathrm{g} \cdot \mathrm{mL}^{-1}$ to calibrate the HPLC. Carbohydrate peaks of the samples were identified according to HPLC retention times in comparison with authentic standards. For recovery tests, samples were spiked with standard solutions before extraction. The detection limit for each sugar was $1 \mu \mathrm{g}$, and the recovery was $95 \%$.

Starch analysis. Starch was determined by combining $30 \mathrm{mg}$ of AIS with $10 \mathrm{~mL}$ distilled water, and heating at $100^{\circ} \mathrm{C}$ in a water bath for 90 min (Hagenimana et al., 1994). A soluble starch standard was included also. After cooling, $5 \mathrm{~mL}$ of $0.01 \mathrm{M}$ sodium acetate $(\mathrm{pH} 4.5)$ containing 10 units $/ \mathrm{mL}$ of amyloglucosidase was added to each sample and the standard. The test tubes were incubated at $55{ }^{\circ} \mathrm{C}$ for $30 \mathrm{~min}$. Following enzymatic hydrolysis, the total reducing sugars were measured using the method of Blakeney and Mutton (1980).

Statistics. Data were subjected to analysis of variance using the GLM procedure in SAS (SAS Institute, 1999). There were four replications of each treatment. Data for starch and sugar concentrations were analyzed using a split block design for three factors (cultivar, dose and storage time). Firmness and color data were analyzed separately by cultivar using a randomized complete block design for two factors (dose and storage time). Data for nondestructive measurements (disease, sprouting, weight loss) were analyzed using a split block design for repeated measures over time. Means were separated using the Waller-

\section{Results and Discussion}

Sweetpotato cultivar and irradiation dose affected the storage quality of roots. After 12 Duncan $\mathrm{k}$ ratio $t$ test. weeks storage at $15{ }^{\circ} \mathrm{C}$, nonirradiated roots lost $3 \%$ to $4 \%$ weight, whereas roots treated with 400 Gy lost $4.7 \%$ to $8.6 \%$ weight (Table 1). Sweetpotato roots can lose up to $10 \%$ of their fresh weight without appearing shriveled (Rubatzky and Yamaguchi, 1997). Irradiated 'Yoshida' roots had higher percent weight loss than 'Mokuau' or 'Okinawan' roots. 'Yoshida' roots were the smallest among the three cultivars. A greater surface area to volume ratio may have contributed to increased moisture loss for 'Yoshida' roots. In a study by McGuire and Sharp (1995), 'Jewel' and 'Picadito' sweetpotato roots lost 5.1\% and $11.4 \%$ weight, respectively, after treatment with 1000 Gy irradiation and storage for 4 weeks at $13{ }^{\circ} \mathrm{C}$. Nonirradiated roots lost $3.8 \%$ to $8.2 \%$ weight.

Weight loss was not related to root sprouting. Irradiation inhibits sprouting in bulbs and tubers at doses of 20 to $90 \mathrm{~Gy}$ (bulbs) and 70 to 150 Gy (tubers) (Thomas, 2001). However, sprouting of sweetpotatoes was negligible for all treatments (data not shown), and was not affected by irradiation dose $(P=0.24)$. Sprouting was observed for 'Yoshida' roots only, with a mean of 0.3 sprouts for all doses. Picha (1986) reported that cured (unirradiated) sweetpotatoes were stored successfully at $15.6{ }^{\circ} \mathrm{C}, 90 \%$ $\mathrm{RH}$ for up to a year without sprouting.

'Yoshida' roots treated with 400 Gy irradiation had the most diseased roots among all treatments (Table 1). These roots were deemed unmarketable, because the disease severity approached a moderate rating. The infected roots had pale brown, spongy advancing lesions and reddish brown to black firm areas. A fungus Macrophomina phaseolina (Tassi) Goid, the causal agent of charcoal rot, was isolated from representative infected roots. Charcoal rot is widespread in the tropics (Snowden, 1992) and has been reported in Hawaii (Raabe et al., 1981). Infection of the crop occurs in the field, but symptoms of charcoal rot develop primarily during storage (Clark and Moyer, 1988). The white-fleshed 'Yoshida' roots may be more susceptible to charcoal rot than the purple-fleshed cultivars. Purple sweetpotatoes contain higher amounts of anthocyanins and

Table 1. Percent weight loss, disease incidence and severity for sweet potatoes treated with $\mathrm{X}$-ray irradiation and stored at $15{ }^{\circ} \mathrm{C}$ for 12 weeks.

${ }^{2}$ Disease incidence is the average number of roots per replication showing disease symptoms. Values are means of four replications, with three roots per replication. Disease severity for each root was rated as 0 (none), 1 (low), 2 (moderate), or 3 (severe) based on visual symptoms.

y Values are means of four replications, with three roots per replication.

Means separated within columns by the Waller Duncan k ratio $t$ test $(P \leq 0.05)$.

${ }^{* * * * * *}$ Significant at $P \leq 0.01$ or 0.001 , respectively.

phenolics than white, yellow, or orange roots et al., 2003), and these antioxidant compounds may confer increased pathogen ense to purple sweetpotatoes. approved by the U.S. Food and Drug Admir tration for the preservation and disinfestation of fruits and vegetables (Federal Register, 1986). However, for most fresh produce, irradiation 000 Gy are needed to achieve postharvest disease control (Morris and Jessup, 994). In potatoes (Solanum tuberosum L.), por varies with cultivar general, susceptibility increases as irradiation 2001). A and susceptible potato tubers with Fusarium, Phytophthora, and Penicillium species, treated the tubers with 0,100 , or $150 \mathrm{~Gy} \gamma$-irradiation, stored the potatoes for 3 months. Irradiaon increased the incidence of rotted tubers storage for the susceptible cultivar wound periderm, and to a decrease in pathogen resistance and wound healing compounds such as phenolics and lignin (Ramamurthy et al., , 2000, Thomas, 1982). However, many studies have shown that when good quality tubers are irradiated and stored, there was no during

Sweetpotato firmness was affected by cultivar, irradiation dose, storage period, $\leq 0.001)$. In gene factors ( $P$ increased root firmness, regardless of treatment (Table 2). In a previous experiment, we also found that roots became firmer after 2 weeks (Wall, 2004). Root periderm thickening may have continued during the storage period. effects on sweetpotato roots irradiated at $400 \mathrm{~Gy}$ were softer than nonirradiated roots before and after 12 weeks storage (Table 2). 'Okinawan' irradiated roots

(200 and 400 Gy) were softer than control

\begin{tabular}{|c|c|c|c|c|}
\hline Cultivar & $\begin{array}{c}\text { Dose } \\
\text { (Grays) }\end{array}$ & $\begin{array}{c}\mathrm{Wt} \\
\operatorname{loss}(\%)\end{array}$ & $\begin{array}{c}\text { Diseased } \\
\text { roots }(\text { no. })^{z}\end{array}$ & $\begin{array}{c}\text { Disease } \\
\text { severity }^{z}\end{array}$ \\
\hline \multirow[t]{3}{*}{ Mokuau } & 0 & $2.99 \mathrm{a}^{\mathrm{y}}$ & $0 \mathrm{a}$ & $0 \mathrm{a}$ \\
\hline & 200 & $4.09 \mathrm{ab}$ & $0 \mathrm{a}$ & $0 \mathrm{a}$ \\
\hline & 400 & $4.67 \mathrm{bc}$ & $0.25 \mathrm{a}$ & $0.25 \mathrm{a}$ \\
\hline \multirow[t]{3}{*}{ Okinawan } & 0 & $3.88 \mathrm{ab}$ & $0.25 \mathrm{a}$ & $0.08 \mathrm{a}$ \\
\hline & 200 & $5.37 \mathrm{c}$ & $0 \mathrm{a}$ & $0 \mathrm{a}$ \\
\hline & 400 & $5.39 \mathrm{c}$ & $0 \mathrm{a}$ & $0 \mathrm{a}$ \\
\hline \multirow[t]{3}{*}{ Yoshida } & 0 & $4.13 \mathrm{ab}$ & $0 \mathrm{a}$ & $0 \mathrm{a}$ \\
\hline & 200 & $6.93 \mathrm{~d}$ & $0 \mathrm{a}$ & $0 \mathrm{a}$ \\
\hline & 400 & $8.59 \mathrm{e}$ & $2.00 \mathrm{~b}$ & $1.55 \mathrm{~b}$ \\
\hline \multicolumn{5}{|c|}{ Main effects and interaction } \\
\hline Cultivar & & $* * *$ & $* * *$ & $* * *$ \\
\hline Dose & & $* * *$ & $* * *$ & $* * *$ \\
\hline Cultivar $\times$ dose & & $* *$ & $* * *$ & $* * *$ \\
\hline \multicolumn{5}{|c|}{$\begin{array}{l}{ }^{2} \text { Disease incidence is the average number of roots per replication showing disease symptoms. Values are } \\
\text { means of four replications, with three roots per replication. Disease severity for each root was rated as } 0 \\
\text { (none), } 1 \text { (low), } 2 \text { (moderate), or } 3 \text { (severe) based on visual symptoms. } \\
\text { y Values are means of four replications, with three roots per replication. }\end{array}$} \\
\hline
\end{tabular}
and severity of mechanical injuries, but in . Roting of irradiated potatoes has been 1959; Shirsat et al., 1991).

HortScience Vol. 40(2) April 2005 
roots only after storage. A similar trend was observed for 'Yoshida' after storage, but the 400-Gy treated roots were much softer than the nonirradiated and 200-Gy treated roots. This was likely related to the increased rotting of 400 Gy-treated 'Yoshida' roots.

In other reports, the effect of irradiation on sweetpotato firmness was dependent on cultivar and dose. McGuire and Sharp (1995) reported that 'Jewel' roots treated with 600 Gy were firmer than control roots after 1 month storage, but the trend reversed at doses above $600 \mathrm{~Gy}$. For the staple-type cultivar, 'Picadito', irradia- tion did not affect root firmness (McGuire and Sharp, 1995). We found that the firmness of a yellow-fleshed clone decreased linearly as irradiation dose increased to $600 \mathrm{~Gy}$, but the firmness of a purple-fleshed clone was not affected by irradiation (Wall, 2004).

'Mokuau' and 'Okinawan' roots had minor differences in external and internal color between control and irradiated roots, before and after storage(Table 2). The interaction between dose and storage were not significant for these two cultivars $(P>0.05)$. However, 'Yoshida' roots treated with 400 Gy and stored for 12

Table 2. Firmness and color of sweetpotato roots treated with $\mathrm{x}$-ray irradiation and stored at $15{ }^{\circ} \mathrm{C}$ for 0 or 12 weeks.

\begin{tabular}{|c|c|c|c|c|c|c|c|c|c|}
\hline \multirow[b]{2}{*}{ Cultivar } & \multirow{2}{*}{$\begin{array}{c}\text { Dose } \\
\text { (Grays) }\end{array}$} & \multirow{2}{*}{$\begin{array}{l}\text { Storage } \\
\text { (weeks) }\end{array}$} & \multirow{2}{*}{$\begin{array}{c}\text { Firmness } \\
(\mathrm{N})\end{array}$} & \multicolumn{3}{|c|}{ External color ${ }^{z}$} & \multicolumn{3}{|c|}{ Internal color ${ }^{2}$} \\
\hline & & & & $\mathrm{L}^{*}$ & $\mathrm{C}^{*}$ & $\mathrm{H}^{\circ}$ & $\mathrm{L}^{*}$ & $\mathrm{C}^{*}$ & $\mathrm{H}^{\circ}$ \\
\hline \multirow[t]{6}{*}{ Mokuau } & 0 & 0 & $128.4 \mathrm{~b}^{\mathrm{y}}$ & $40.8 \mathrm{a}$ & $19.6 \mathrm{~b}$ & $26.1 \mathrm{~b}$ & $40.9 \mathrm{a}$ & $31.9 \mathrm{~b}$ & $346.6 \mathrm{a}$ \\
\hline & & 12 & $162.4 \mathrm{a}$ & $41.6 \mathrm{a}$ & $20.6 \mathrm{a}$ & $31.4 \mathrm{a}$ & $40.7 \mathrm{a}$ & $35.1 \mathrm{a}$ & $346.3 \mathrm{a}$ \\
\hline & 200 & 0 & $120.6 \mathrm{bc}$ & $41.0 \mathrm{a}$ & $19.1 \mathrm{~b}$ & $30.8 \mathrm{a}$ & $40.5 \mathrm{a}$ & $31.8 \mathrm{~b}$ & $348.2 \mathrm{a}$ \\
\hline & & 12 & $155.6 \mathrm{a}$ & $41.8 \mathrm{a}$ & $20.0 \mathrm{ab}$ & $32.1 \mathrm{a}$ & $41.3 \mathrm{a}$ & $34.4 \mathrm{a}$ & $347.2 \mathrm{a}$ \\
\hline & 400 & 0 & $110.4 \mathrm{c}$ & $41.3 \mathrm{a}$ & $19.3 \mathrm{~b}$ & $28.6 \mathrm{ab}$ & $40.8 \mathrm{a}$ & $31.1 \mathrm{~b}$ & $347.7 \mathrm{a}$ \\
\hline & & 12 & $128.7 \mathrm{~b}$ & $41.9 \mathrm{a}$ & $19.3 b$ & $31.1 \mathrm{a}$ & $40.5 \mathrm{a}$ & $31.2 \mathrm{~b}$ & $348.3 \mathrm{a}$ \\
\hline \multirow[t]{6}{*}{ Okinawan } & 0 & 0 & $109.0 \mathrm{c}$ & $66.3 \mathrm{ab}$ & $23.4 \mathrm{~b}$ & $75.3 \mathrm{a}$ & $47.2 \mathrm{c}$ & $33.7 \mathrm{a}$ & $344.1 \mathrm{a}$ \\
\hline & & 12 & $164.3 \mathrm{a}$ & $64.8 \mathrm{bc}$ & $24.8 \mathrm{a}$ & $73.6 \mathrm{~b}$ & $50.6 \mathrm{ab}$ & $30.6 \mathrm{~b}$ & $344.0 \mathrm{a}$ \\
\hline & 200 & 0 & $106.3 \mathrm{c}$ & $65.8 \mathrm{bc}$ & $24.2 \mathrm{a}$ & $74.5 \mathrm{ab}$ & $47.8 \mathrm{bc}$ & $33.4 \mathrm{a}$ & $344.9 \mathrm{a}$ \\
\hline & & 12 & $142.3 \mathrm{~b}$ & $64.1 \mathrm{c}$ & $24.7 \mathrm{a}$ & $73.5 \mathrm{~b}$ & $48.5 \mathrm{bc}$ & $32.5 \mathrm{a}$ & $345.5 \mathrm{a}$ \\
\hline & 400 & 0 & $102.2 \mathrm{c}$ & $67.7 \mathrm{a}$ & $24.0 \mathrm{ab}$ & $74.8 \mathrm{a}$ & $47.6 \mathrm{bc}$ & $33.2 \mathrm{a}$ & $345.0 \mathrm{a}$ \\
\hline & & 12 & $137.9 \mathrm{~b}$ & $66.8 \mathrm{ab}$ & $24.6 \mathrm{a}$ & $74.8 \mathrm{a}$ & $52.4 \mathrm{a}$ & $30.1 \mathrm{~b}$ & $347.0 \mathrm{a}$ \\
\hline \multirow[t]{6}{*}{ Yoshida } & 0 & 0 & $110.1 \mathrm{c}$ & $49.4 \mathrm{~b}$ & $23.0 \mathrm{~b}$ & $40.9 \mathrm{~d}$ & $89.8 \mathrm{a}$ & $12.1 \mathrm{c}$ & $93.4 \mathrm{a}$ \\
\hline & & 12 & $165.2 \mathrm{a}$ & $51.1 \mathrm{a}$ & $24.5 \mathrm{a}$ & $44.7 \mathrm{bc}$ & $89.4 \mathrm{a}$ & $12.6 \mathrm{bc}$ & $92.6 \mathrm{a}$ \\
\hline & 200 & 0 & $109.0 \mathrm{c}$ & $49.4 \mathrm{~b}$ & $23.0 \mathrm{~b}$ & $43.7 \mathrm{bc}$ & $89.5 \mathrm{a}$ & $13.7 \mathrm{~b}$ & $93.1 \mathrm{a}$ \\
\hline & & 12 & $137.9 \mathrm{~b}$ & $51.6 \mathrm{a}$ & $24.1 \mathrm{ab}$ & $46.6 \mathrm{~b}$ & $87.7 \mathrm{a}$ & $12.6 \mathrm{bc}$ & $92.2 \mathrm{a}$ \\
\hline & 400 & 0 & $106.2 \mathrm{c}$ & $50.7 \mathrm{ab}$ & $23.2 \mathrm{~b}$ & $42.1 \mathrm{~cd}$ & $89.4 \mathrm{a}$ & $13.1 \mathrm{bc}$ & $93.1 \mathrm{a}$ \\
\hline & & 12 & $82.4 \mathrm{~d}$ & $49.7 \mathrm{ab}$ & $20.6 \mathrm{c}$ & $50.5 \mathrm{a}$ & $75.0 \mathrm{~b}$ & $16.9 \mathrm{a}$ & $87.4 \mathrm{~b}$ \\
\hline
\end{tabular}

${ }^{2}$ Lightness ( $\left.\mathrm{L}^{*}\right)$ values range from 0 for black to 100 for white; chroma $\left(\mathrm{C}^{*}\right)$ values range from 0 for least saturation to 60 for full saturation; hue angle $\left(\mathrm{H}^{\circ}\right)$ ranges from $0^{\circ}$ to $360^{\circ}$ where $0^{\circ}$ or $360^{\circ}$ is red-purple, $90^{\circ}$ is yellow, $180^{\circ}$ is blue-green, and $270^{\circ}$ is purple-blue.

yValues are means of four replications, with three roots per replication. Means separated within columns and cultivars by the Waller Duncan k ratio $t$ test $(P \leq 0.05)$.

Table 3. Starch and sugar content of sweetpotatos treated with $\mathrm{x}$-ray irradiation and stored at $15^{\circ} \mathrm{C}$ for 0 or 12 weeks.

\begin{tabular}{|c|c|c|c|c|c|c|c|}
\hline \multirow[b]{2}{*}{ Cultivar } & \multirow{2}{*}{$\begin{array}{c}\text { Dose } \\
\text { (Grays) }\end{array}$} & \multirow{2}{*}{$\begin{array}{l}\text { Storage } \\
\text { (weeks) }\end{array}$} & \multicolumn{5}{|c|}{ Content (mg $\cdot \mathrm{g}^{-1}$ fresh wt) } \\
\hline & & & Starch & Glucose & Fructose & Sucrose & Total \\
\hline \multirow[t]{6}{*}{ Mokuau } & 0 & 0 & $190.66 \mathrm{a}$ & $3.76 \mathrm{ab}$ & $2.55 \mathrm{ab}$ & $23.71 \mathrm{a}$ & $30.02 \mathrm{a}$ \\
\hline & & 12 & $207.61 \mathrm{a}$ & $4.99 \mathrm{a}$ & $3.80 \mathrm{a}$ & $24.66 \mathrm{a}$ & $33.45 \mathrm{a}$ \\
\hline & 200 & 0 & $201.18 \mathrm{a}$ & $3.39 \mathrm{ab}$ & $2.08 \mathrm{~b}$ & $26.26 \mathrm{a}$ & $31.73 \mathrm{a}$ \\
\hline & & 12 & $206.67 \mathrm{a}$ & $4.60 \mathrm{a}$ & $4.01 \mathrm{a}$ & $25.94 \mathrm{a}$ & $34.55 \mathrm{a}$ \\
\hline & 400 & 0 & $201.84 \mathrm{a}$ & $2.25 \mathrm{~b}$ & $1.12 \mathrm{~b}$ & $26.01 \mathrm{a}$ & $29.38 \mathrm{a}$ \\
\hline & & 12 & $177.49 \mathrm{a}$ & $4.52 \mathrm{a}$ & $3.59 \mathrm{a}$ & $49.20 \mathrm{~b}$ & $57.31 \mathrm{~b}$ \\
\hline \multirow[t]{6}{*}{ Okinawan } & 0 & 0 & $181.19 \mathrm{a}$ & $0.99 \mathrm{c}$ & $0.96 \mathrm{c}$ & $35.71 \mathrm{a}$ & $37.66 \mathrm{a}$ \\
\hline & & 12 & $206.39 \mathrm{a}$ & $3.64 \mathrm{~b}$ & $2.66 \mathrm{~b}$ & $35.64 \mathrm{a}$ & $41.94 \mathrm{~b}$ \\
\hline & 200 & 0 & $187.13 \mathrm{a}$ & $1.20 \mathrm{c}$ & $0.99 \mathrm{c}$ & $38.42 \mathrm{a}$ & $40.61 \mathrm{ab}$ \\
\hline & & 12 & $177.42 \mathrm{a}$ & $5.44 \mathrm{a}$ & $4.02 \mathrm{a}$ & $52.60 \mathrm{~b}$ & $62.06 \mathrm{c}$ \\
\hline & 400 & 0 & $187.36 \mathrm{a}$ & $0.55 \mathrm{c}$ & $0.33 \mathrm{c}$ & $38.54 \mathrm{a}$ & $39.42 \mathrm{ab}$ \\
\hline & & 12 & $158.81 \mathrm{a}$ & $6.09 \mathrm{a}$ & $3.75 \mathrm{ab}$ & $61.73 \mathrm{c}$ & $71.57 \mathrm{~d}$ \\
\hline \multirow[t]{6}{*}{ Yoshida } & 0 & 0 & $185.14 \mathrm{a}$ & $0.91 \mathrm{~b}$ & $0.33 \mathrm{~b}$ & $32.82 \mathrm{a}$ & $34.06 \mathrm{a}$ \\
\hline & & 12 & $177.88 \mathrm{a}$ & $4.33 \mathrm{a}$ & $3.37 \mathrm{ab}$ & $31.11 \mathrm{a}$ & $38.81 \mathrm{a}$ \\
\hline & 200 & 0 & $138.16 \mathrm{~b}$ & $4.58 \mathrm{a}$ & $2.99 \mathrm{ab}$ & $32.32 \mathrm{a}$ & $39.89 \mathrm{a}$ \\
\hline & & 12 & $179.82 \mathrm{a}$ & $3.76 \mathrm{a}$ & $3.64 \mathrm{ab}$ & $31.78 \mathrm{a}$ & $39.18 \mathrm{a}$ \\
\hline & 400 & 0 & $178.81 \mathrm{a}$ & $2.31 \mathrm{ab}$ & $1.85 \mathrm{~b}$ & $35.75 \mathrm{a}$ & $39.91 \mathrm{a}$ \\
\hline & & 12 & $120.25 \mathrm{~b}$ & $4.56 \mathrm{a}$ & $4.54 \mathrm{a}$ & $66.04 \mathrm{~b}$ & $75.14 \mathrm{~b}$ \\
\hline \multicolumn{8}{|c|}{ Main effects and interactions } \\
\hline Cultivar & & & $* * *$ & NS & $*$ & $* * *$ & $* * *$ \\
\hline Dose & & & $* *$ & NS & NS & $* * *$ & $* * *$ \\
\hline Storage & & & NS & $* * *$ & $* * *$ & $* * *$ & $* * *$ \\
\hline Cultivar & & & NS & NS & NS & $* *$ & $* *$ \\
\hline Cultivar & rage & & NS & $*$ & NS & NS & NS \\
\hline Dose $\times$ & & & $* *$ & NS & NS & $* * *$ & $* * *$ \\
\hline Cultivar & e $\times$ stora & & NS & NS & NS & $*$ & $*$ \\
\hline
\end{tabular}

${ }^{2}$ Values are means of four replications, with a composite sample of three roots per replication. Means separated within columns and cultivars by the Waller Duncan k ratio $t$ test $(P \leq 0.05)$.

NS $, *, * *, * * *$ Nonsignificant or significant at $P \leq 0.05,0.01$, or 0.001 , respectively. weeks had an external color that was more orange (higher hue angle) and less saturated (lower chroma), and an internal color that was darker and less yellow (lower L* and hue angle values), than control roots (Table 2). For 'Yoshida', color changes were related to postharvest decay.

$\mathrm{Lu}$ et al.(1986) reported that doses of gamma irradiation up to 2000 Gy had no effect on sweetpotato color. McGuire and Sharp (1995) found imperceptible changes in peel color for the orange-fleshed 'Jewel' and whitefleshed 'Picadito' roots following irradiation. However, the internal color of 'Picadito' became more yellow-gray (McGuire and Sharp, 1995). Irradiation did not cause browning or perceptible discoloration of red-skin, yellowfleshed or white-skin, purple fleshed roots in a previous study (Wall, 2004).

When all cultivars were averaged, sweetpotatoes treated with $400 \mathrm{~Gy}$ and stored for 12 weeks had the lowest starch concentrations (Table 3). Glucose and fructose concentrations were not affected by irradiation $(P>0.05)$, but these sugars increased during storage $(P$ $\leq 0.001$ ) (Table 3). Cultivar, dose, and storage impacted sweetpotato sucrose and total sugar concentrations $(P \leq 0.001)$. When 'Mokuau' and 'Yoshida' roots were irradiated with 400 Gy and stored for 12 weeks, sucrose concentrations were double those of nontreated roots (Table 3). For 'Okinawan'roots, 200 and 400 Gy doses increased sucrose contents by 48 to $73 \%$ after storage. The increases in total sugar concentrations paralleled the decreases in starch contents of sweetpotatoes irradiated with 400 Gy and stored for 12 weeks.

Sucrose has been shown to increase, and starch to decrease, during curing and storage of nonirradiated sweetpotatoes (Picha, 1987). However, after 12 weeks storage, sucrose concentrations had not increased in nonirradiated 'Mokuau', 'Okinawan', and 'Yoshida' roots (Table 3). Others have reported that total sugar content increased with irradiation doses over $500 \mathrm{~Gy}$, depending on cultivar (Lu et al., 1986). In a previous study, starch concentration decreased and sucrose concentration increased linearly in response to irradiation dose, and 600 Gy-treated sweetpotatoes were perceived as sweeter than nonirradiated roots by a sensory panel (Wall, 2004).

\section{Conclusions}

The interaction between irradiation dose and storage was more important for the quality of white-fleshed 'Yoshida', than for purple-fleshed 'Mokuau' or 'Okinawan' sweetpotatoes.

Any reduction in quality following irradiation and storage was attributed to softening and postharvest disease, and these factors were cultivar and dose dependent. For 'Yoshida', postharvest decay adversely impacted the internal color, firmness, and overall quality of roots treated with 400 Gy irradiation and stored for 12 weeks. 'Mokuau' and 'Okinawan' retained good quality, largely because they did not have storage rots. The purple 'Okinawan' sweetpotato is the primary export cultivar 
from Hawaii. Since USDA-APHIS approved the movement of irradiated sweetpotatoes from Hawaii (Federal Register, 2004), about 18,000 to $22,500 \mathrm{~kg}$ of 'Okinawan' roots are irradiated and shipped weekly. Also, research is in progress to lower the minimum irradiation dose to $<250$ Gy (Follett, 2004). For quality assurance of irradiated sweetpotatoes, healthy roots of purple-fleshed cultivars should be harvested from disease-free fields, handled gently, cured properly, and stored under optimum conditions.

\section{Literature Cited}

Ahmed, E.S. 1975. Increasing rotting in irradiated potatoes in relation to phytoalexin, rishitin and phytoberin formation. Egypt J. Hort. 2:187-197.

Baraldi, D. 1978. Technological tests at the preindustrial level of irradiated potatoes, p. 155-166. In: Food preservation by irradiation. vol.1. Intl. Atomic Energy Agency, Vienna.

Blakeney, A.B. and L.L. Mutton. 1980. Simple colorimetric method for the determination of sugars in fruit and vegetables. J. Sci. Food Agr. 31:889-897.

Clark, C.A. and J.W. Moyer. 1988. Compendium of sweetpotato diseases. APS Press, St. Paul, Minn.

Duncan, D.T., W.J. Hooker, and F. Heiligman. 1959. Storage rot susceptibility of potato tubers exposed to minimum sprout inhibiting levels of ionizing radiation. Food Technol. 13:159-164.

Federal Register. 1986. Irradiation in the production, processing and handling of food: final rule. Rules and Regulations 51(75):13375-13399.

Federal Register. 2004. Irradiation of sweetpotatoes from Hawaii. Rules and Regulations 69(32):7541-7547.
Follett, P.A. 2004. Irradiation to control insects in fruits and vegetables for export from Hawaii. Radiation Physics Chem. 71:163-166.

Hagenimana, V., R.E. Simard, and L. Vezina. 1994. Amylolytic activity in germinating sweetpotato (Ipomoea batatas L.) roots. J. Amer. Soc. Hort. Sci. 119:313-320.

Hallman, G.J. 2001. Ionizing irradiation quarantine treatment against sweetpotato weevil (Coleoptera: Curculionidae). Fla. Entomol. 84:415-417.

Lu, J.Y., S. White, P. Yakubu, and P.A. Loretan. 1986. Effects of gamma radiation on nutritive and sensory qualities of sweetpotato storage roots. J. Food Qual. 9:425-435.

McGuire, R.G. and J.L. Sharp. 1995. Market quality of sweetpotatoes after gamma-irradiation for weevil control. HortScience 30:1049-1051.

Morris, S.C. and A.J. Jessup. 1994. Irradiation, p. 163-190. In: R.E. Paull and J.W. Armstrong (eds.). Insect pests and fresh horticultural products: Treatments and responses. CAB Intl., Wallingford, U.K.

Philpott, M., K.S. Gould, K.R. Markham, S.L. Lewthwaite, and L.R. Ferguson. 2003. Enhanced coloration reveals high antioxidant potential in new sweetpotato cultivars. J. Sci. Food Agr. 83:1076-1082.

Picha, D.H. 1985. HPLC determination of sugars in raw and baked sweetpotatoes. J. Food Sci. 50:1189-1190.

Picha, D.H. 1986. Weight loss in sweetpotatoes during curing and storage: Contribution of transpiration and respiration. J. Amer. Soc. Hort. Sci. 111:889-892.

Picha, D.H. 1987. Carbohydrate changes in sweet potatoes during curing and storage. J.Amer. Soc. Hort. Sci. 112:89-92.

Raabe, R.D, I.L. Conners, and A.P. Martinez. 1981. Checklist of plant diseases in Hawaii. College Trop. Agr. Human Res. Univ. Hawaii Info. Text Ser. 22.
Ramamurthy, M.S., B. Maiti, P. Thomas, and P.M. Nair. 1992. High-performance liquid chromatography determination of phenolic acids in potato tubers (Solanum tuberosum) during wound healing. J. Agr. Food Chem. 40:569-572.

Ramamurthy, M.S., K.K. Ussuf, P.M. Nair, and P. Thomas. 2000. Lignin biosynthesis during wound healing of potato tubers in response to gamma irradiation. Postharv. Biol. Technol. 18:267-272.

Rubatzky, V.E. and M. Yamaguchi. 1997. World vegetables: Principles, production and nutritive values. 2nd ed. Chapman and Hall, New York.

SAS Institute. 1999. SAS system for Windows. version 8. SAS Inst., Cary, N.C.

Shirsat, S.G., P. Thomas, and P.M. Nair. 1991. Evaluation of treatments with hot water, chemicals and ventilated containers to reduce microbial spoilage in irradiated potatoes. Potato Res. 34:227-321.

Snowdon, A.L. 1992. Color atlas of post-harvest diseases and disorders of fruits and vegetables. vol. 2. Vegetables. CRC Press, Boca Raton, Fla.

Thomas, P. 1982. Wound-induced suberization and periderm development in potato tubers as affected by temperature and gamma irradiation. Potato Res. 25:155-164.

Thomas, P. 2001. Irradiation of tuber and bulb crops, p. 241-271. In: R.A. Molins (ed.). Food irradiation: Principles and applications. John Wiley and Sons, Inc., New York.

U.S. Department of Agriculture-APHIS-PPQ. 2002. Qualitative pathway-initiated risk assessment of the importation of fresh sweetpotato, Ipomoea batatas L. Lam., from Hawaii into the continental United States. Plant Protection and Quarantine, Riverdale, Md.

Wall, M.M. 2004. Compositional and sensory analyses of Hawaii-grown sweetpotatoes after x-ray irradiation quarantine treatment. HortScience 39:574-577. 